BOROZENETS V.V. ${ }^{1 凶}$, BABALIAN V.O. ${ }^{2}$, FEDOTAO.M. ${ }^{1}$

${ }^{1}$ V.N. Karazin Kharkiv National University,

Ukraine, 61058, Kharkiv, Svoboda sq., 6, e-mail: amsfedota@gmail.com

${ }^{2}$ Kharkiv Medical Academy of Postgraduate Education,

Ukraine, 61176, Kharkiv, Amosova str., 58,e-mail: babalyanvladimir@gmail.com

凶Vikaborozenets1984@gmail.com, (097) 629-52-37

\title{
GENETIC ASPECTS OF LACTASE PERSISTENCE IN DIFFERENT ETHNIC GROUPS
}

Aim. The aim of this study was evaluation of the genetic aspects of lactase persistence (LP) in persons from different ethnic groups. Methods. Genealogical and medical information was collected about Ukrainian, Indian, Nigerian, Israel, Egypt, Palestine, Turkey, Jordan students $(n=361)$ and their first degree relatives $(n=413)$. Statistical analysis was carried out by Shapiro-Wilk test, $\chi^{2}$, Spearman correlation. Results. The phenotype of LP was found in $69.9 \%$ of Ukrainians, lactose intolerance - in $7.2 \%$. The highest LP is observed in $95.2 \%$ of Nigerians, the lowest - Palestinians, $51.9 \%$. Analysis in all ethnic groups showed that the number of LP people is less among parents than among students $(r=-0.529, \mathrm{p}<0.05)$. The LP score is $72.7-95.2 \%$ among Nigerian, Israeli, Egyptian, Turkish, Indian students, and $60-76.5 \%$ among their parents. The LP phenotype is $50-68.8 \%$ and $53.9-70.9 \%$ among Ukrainian, Palestinian Jordanian students and their parents. It is likely that adult-type hypolactasia may appear after 20 years and older, indicating a high degree of heterozygosity. The highest number of persons with first exogamy degree is $82.6-85.5 \%$ among Turks, Palestinians, Egyptians and the lowest value of LP phenotype is observed in these groups - $51.9-72.3 \%$, (r $=-0.786, p<0.05)$. A positive correlation is determined between the traits of hypolactasia and first degree of parents exogamy $(r=0.905, p<0.05)$. The changes in metabolic status with age could be a predictor for multifactorial pathology. Conclusions. Adult hypolactasia is an age-dependent trait. Relations between the parameters of LP and the origin were established.

Keywords: lactase persistence, lactose intolerance, exogamy, genotypes.

Continued production of lactase throughout adult life - lactase persistence(LP) is found at moderate to high frequencies in Europeans and some African, Middle Eastern and Southern Asian populations $[1,2]$.Many intolerant individuals could tol- erate low levels of lactose in their daily diet [3].According to the National Library of Medicine data, lactose intolerance in adulthood is most prevalent in people of East Asian descent, affecting more than 90 percent of adults in some of these communities[4].Lactose intolerance is also very common in people of West African, Arab, Jewish, Greek, and Italian descent.

Currently, it is believed that in different ethnic groups the trait of LP is associated with at least five independent single nucleotide variants in a regulatory region about $14 \mathrm{~kb}$ upstream of the lactase gene $[-13910 * \mathrm{~T} \quad(\mathrm{rs} 4988235), \quad-13907 * \mathrm{G}$ (rs41525747), $-13915 * \mathrm{G}(\mathrm{rs} 41380347),-14009 * \mathrm{G}$ (rs869051967) and $-14010 * \mathrm{C}(\mathrm{rs} 145946881)]$ [5].

The aim of this study was evaluation of the genetic aspects of lactase tolerance in persons from different ethnic groups.

\section{Materials and methods}

Genealogical and medical information was collected about Ukrainian, Indian, Nigeria, Middle East Countries (Israel, Egypt, Palestine, Turkey, Jordan) students. The number of people participating in the study was 774 , male -370 , female -404 , ages from 14 to 69 years. The data were divided into two groups: about students aged 17 to 30 years old and their parents aged 38 to 67 years old. The students average age was $22.2 \pm 1.09$ years, parents $-49.2 \pm 2.74$ years. Each group was classified according to ethnicity, age, gender, degree of parents exogamy. The survey on the consumption and assimilation of cow's milk and dairy products was conducted on a scale: from the 1st-always consumed to the 3rd - never consumed. The method of exogamy degree estimation was described previously [6].Statistical analysis had been carried out using Shapiro-Wilk test for normality, Chi-square test, Spearman correlation.

\footnotetext{
${ }^{\circ}$ BOROZENETS V.V., BABALIAN V.O., FEDOTAO.M.1
} 


\section{Results and discussion}

The analysis of the results obtained in the Ukrainians study indicated that lactose persistence phenotype is found in $69.9 \%$ of persons and lactase intolerance - in approximately $7.2 \%$. The highest LP phenotype is observed in Nigerians - $95.2 \%$ and none of them has lactose intolerance. It is detected that only $51.9 \%$ of Palestine subjects were consuming milk. The proportion of people with lactose persistence among students and parents in most countries is not comparable $(\chi 2=23.56, \mathrm{p}=$ $0.0014)$.Analysis in all ethnic groups showed that the frequency of lactose tolerance is less among parents than among students. A significant negative correlation between percentage of persons with lactose persistence and age have been revealed, $\mathrm{r}=$ - $0.529(\mathrm{p}<0.05)$. Our results are in world data trends .It is known that the genotype associated adult-type hypolactasia, especially associated with genotype $\mathrm{C} / \mathrm{C}-13910$, begins at an early age with a further decrease to complete loss. Age varies among ethnic groups, ranging from 1 to 20 years. Whereas in the literature there are no exact data on the onset age of a decrease in lactase activity. For example, a study by Rasinperä H. and employees showed differences in African and Finnish children and revealed that the decline of lactase activity was somewhat earlier in African compared with Finnish children[7].

In our investigation the LP score is 72.7 95.2 \% among Nigerian, Israeli, Egyptian, Turkish, Indian students, and $60-76.5 \%$ among their parents. In accordance with the data obtained, it could be assumed that students from India, Nigeria, Israel, Egypt, Turkey maintain the absorption of lactose longer at a young age, and not lose ability in early childhood. Really, according Seppo L. although primary hypolactasia normally appears before the age of 20 years, the decline in lactase activity may on occasions continue after that age [8]. In investigation by Bulhões A. et al. [9]demonstrated that one of the 10 subjects with the CCGG genotype (lactase non-persistence) had negative hydrogen breath test, without symptoms. This could be explained by a slow decrease of lactase levels, with hypolactasia developing later in life [9].It is likely that adult-type hypolactasia may appear after 20 years and older, and could indicating a high degree of heterozygosity.

The analysis of Ukraine, Palestine and Jordan groups showed that lactose tolerance phenotype in students and parents are comparable. The LP phenotype is $50-68.8 \%$ and $53.9-70.9 \%$ among
Ukrainian, Palestinian Jordanian students and parents. We concluded that students from these ethnic groups at the age of 20 years have achieved a trait of lactose tolerance. The results of studies are shown in Table 1.

An analysis of individuals distribution according to the parents exogamy degree (Table. 2) showed that the highest number of persons with first exogamy degree is $82.6-85.5 \%$ among Turks, Palestinians, Egyptians and the lowest value of LP phenotype is observed in these groups - 51.9 $72.3 \%$.

A statistically significant negative correlation between the parameters of first degree of parents exogamy and lactose persistence phenotype was found, $r=-0.786(p<0.05)$.

In all ethnic groups a statistically significant positive correlation between the trait of adult-type hypolactasia and number of persons with the first degree of parents exogamy is determined, $r=0.905$ $(\mathrm{p}<0.05)$.

The results obtained about the influence of the individuals origin on the trait under study may be related to the effect of the exogamy degree on the frequency of genetic recombination [10-12].

The tendency for associative marriages has the effect of increasing the inbreeding level. It leads to a decrease in genetic diversity, an increase in the number of similar loci in chromosomes during conjugation, and thus to an increase in the recombination processes associated with chromosome rearrangements, and consequently to a decrease the number of homozygotes [13].The results of our previous studies have shown that people who consumed milk and dairy products in childhood and decreased this ability with age had heterozygous genotypes: CTGA of SNPs- 13910C-T (rs4988235) and 22018G-A (rs 182549) of MCM6gene [6]. Therefore, the results of this study are consistent with previous findings.

We also proposed that LI should not be regarded as an isolated trait but considered as a possible trigger for further diseases. The change in metabolic status with age could be a predictor for multifactorial pathology.

Lactose intolerance is the risk factor for fractures and osteoporosis but is also could associated with gastrointestinal pathologies. Our results obtained previously indicate that patients with CTGA genotype had osteoporosis and disorders of the gastrointestinal tract, such as gastritis (43\%), peptic ulcer $(29 \%)$, stomach cancer $(12.5 \%)$ and others [6]. 
Table 1. Distribution of milk consumption trait in different ethnic groups

\begin{tabular}{|c|c|c|c|c|c|}
\hline \multirow{2}{*}{$\begin{array}{l}\text { Inhabitants } \\
\text { of the coun- } \\
\text { tries }\end{array}$} & \multirow{2}{*}{$\begin{array}{c}\text { Age range, } \\
\text { min - max, } \\
\text { years old }\end{array}$} & \multirow[b]{2}{*}{$\mathrm{N}$} & \multicolumn{3}{|c|}{ Consumption of cow's milk, $\%$} \\
\hline & & & Life-long & Lose with age & Never \\
\hline \multirow[t]{2}{*}{ Nigeria } & $\begin{array}{c}17-25 \\
20.8 \pm 0.56\end{array}$ & 21 & 95.2 & 4.8 & 0.0 \\
\hline & $\begin{array}{c}38-61 \\
48.0 \pm 0.28\end{array}$ & 17 & 76.5 & 23.5 & 0.0 \\
\hline Average & 34.4 & 38 & 85.9 & 14.1 & 0.0 \\
\hline \multirow[t]{2}{*}{ Israel } & $\begin{array}{c}19-27 \\
24.0 \pm 0.51\end{array}$ & 19 & 78.9 & 15.8 & 5.3 \\
\hline & $\begin{array}{c}38-63 \\
49.4 \pm 1.18 \\
\end{array}$ & 21 & 66.8 & 28.8 & 4.8 \\
\hline Average & 36.7 & 40 & 72.8 & 22.2 & 5.0 \\
\hline \multirow[t]{2}{*}{ Palestine } & $\begin{array}{c}19-27 \\
22.5 \pm 1.03\end{array}$ & 8 & 50.0 & 50.0 & 0.0 \\
\hline & $\begin{array}{c}39-67 \\
50.8 \pm 1.31 \\
\end{array}$ & 26 & 53.9 & 23.1 & 11.5 \\
\hline Average & 36.7 & 34 & 51.9 & 36.5 & 5.8 \\
\hline \multirow[t]{2}{*}{ Egypt } & $\begin{array}{c}19-24 \\
21.5 \pm 0.65 \\
\end{array}$ & 11 & 72.7 & 27.3 & 0.0 \\
\hline & $\begin{array}{c}40-61 \\
51.7 \pm 1.99\end{array}$ & 9 & 55.6 & 44.4 & 0.0 \\
\hline Average & 36.6 & 20 & 64.1 & 35.9 & 0.0 \\
\hline \multirow[t]{2}{*}{ Turkey } & $\begin{array}{c}17-27 \\
22.5 \pm 0.76\end{array}$ & 13 & 84.6 & 15.4 & 0.0 \\
\hline & $\begin{array}{c}40-69 \\
49.1 \pm 2.77\end{array}$ & 10 & 60 & 40 & 0.0 \\
\hline Average & 35.8 & 23 & 72.3 & 27.7 & 0.0 \\
\hline \multirow[t]{2}{*}{ Jordan } & $\begin{array}{c}22-25 \\
23.6 \pm 0.22\end{array}$ & 16 & 62.5 & 25.0 & 12.5 \\
\hline & $\begin{array}{c}40-67 \\
51.9 \pm 1.67\end{array}$ & 18 & 66.7 & 22.2 & 11.1 \\
\hline Average & 37.8 & 34 & 64.6 & 23.6 & 11.8 \\
\hline \multirow{2}{*}{ India } & $\begin{array}{c}18-28 \\
22.0 \pm 2.30 \\
\end{array}$ & 103 & 81.2 & 15.3 & 3.5 \\
\hline & $\begin{array}{c}40-62 \\
46.9 \pm 6.95\end{array}$ & 61 & 73.3 & 20.0 & 6.7 \\
\hline Average & 34.5 & 164 & 77.3 & 17.7 & 5.1 \\
\hline \multirow{2}{*}{ Ukraine } & $\begin{array}{c}17-30 \\
20.9 \pm 2.66\end{array}$ & 170 & 68.8 & 25.3 & 5.9 \\
\hline & $\begin{array}{c}38-66 \\
45.9 \pm 5.76\end{array}$ & 251 & 70.9 & 20.8 & 8.4 \\
\hline Average & 33.4 & 421 & 69.9 & 23.1 & 7.2 \\
\hline
\end{tabular}

Note. $\mathrm{N}$ - the number of persons interviewer. 
Table 2. Distribution of persons by degrees of parents exogamy, $\%$

\begin{tabular}{|l|c|c|c|c|}
\hline \multirow{2}{*}{ Inhabitants } & \multicolumn{4}{|c|}{ Degree of parents exogamy } \\
\cline { 2 - 5 } & $\mathrm{I}^{\text {st }}$ & $\mathrm{II}^{\text {nd }}$ & $\mathrm{III}^{\text {rd }}$ & $\mathrm{IV}^{\text {th }}$ \\
\hline Nigeria & 18.4 & 73.7 & 7.9 & 0.0 \\
\hline Ukraine & 25.5 & 37.3 & 29.4 & 7.8 \\
\hline India & 37.3 & 62.7 & 0.0 & 0.0 \\
\hline Israel & 75.0 & 22.5 & 2.5 & 0.0 \\
\hline Jordan & 76.5 & 17.7 & 5.9 & 0.0 \\
\hline Turkey & 82.6 & 8.7 & 4.4 & 4.4 \\
\hline Palestine & 84.9 & 12.1 & 3.0 & 0.0 \\
\hline Egypt & 85.5 & 5.0 & 0.0 & 0.0 \\
\hline
\end{tabular}

\section{Conclusions}

The lactase persistence indices have a negative correlation with age. Analysis in all ethnic groups showed that the number of lactose tolerance people is less among parents than among students.
The parameters of first degree of parents exogamy have a negative correlation with the lactase persistence and a positive correlation with trait of adulttype hypolactasia. The obtain results could be the basis for future researches.

\section{References}

1. Gallego Romero I., Basu Mallick C., Liebert A., Crivellaro F., Chaubey G., Itan Y., Metspalu M., Eaaswarkhanth M., Pitchappan R., Villems R., Reich D., Singh L., Thangaraj K., Thomas M.G., Swallow D.M., Mirazón Lahr M., Kivisild T. Herders of Indian and European Cattle Share Their Predominant Allele for Lactase Persistence. Molecular Biology and Evolution. 2012. Vol. 29 (1). P. 249-260. doi: 10.1093/molbev/msr190.

2. Itan Y., Jones B.L., Ingram C.J., Swallow D.M., Thomas M.G. A worldwide correlation of lactase persistence phenotype and genotypes. BMC Evol Biol. 2010. Vol. 10. P. 36. doi: 10.1186/1471-2148-10-36.

3. Ugidos-Rodríguez S., Matallana-González M.C., Sánchez-Mata M.C. Lactose malabsorption and intolerance: a review. Food Funct. 2018. Vol. 9 (8). P. 4056-4068. doi: 10.1039/c8fo00555a.

4. Cho E., Smith-Warner S.A., Spiegelman D., Beeson W.L., van den Brandt P.A., Colditz G.A., Folsom A.R., Fraser G.E., Freudenheim J.L., Giovannucci E., Goldbohm R.A., Graham S., Miller A.B., Pietinen P., Potter J.D., Rohan T.E., Terry P., Toniolo P., Virtanen M.J., Willett W.C., Wolk A., Wu K., Yaun S.S., Zeleniuch-Jacquotte A., Hunter D.J. Dairy foods, calcium, and colorectal cancer: a pooled analysis of 10 cohort studies. J Natl Cancer Inst. 2004. Vol. 96 (13). P. 1015-1022. doi: 10.1093/jnci/djh185.

5. Liebert A., López S., Jones B.L., Montalva N., Gerbault P., Lau W., Thomas M.G., Bradman N., Maniatis N., Swallow D.M. World-wide distributions of lactase persistence alleles and the complex effects of recombination and selection. HumGenet. 2017. Vol. 136 (11-12). P. 1445-1453. doi: 10.1007/s00439-017-1847-y.

6. Fedota O., Babalian V., Borozenets V., Mazniakov S., Puzik N. Lactose intolerance and its association with the exogamy degree among the population of eastern Ukraine. Factors in Experimental Evolution of Organisms. 2019. № 24. P. $249-253$. [in Ukrainian] / Федота О.М., Бабалян В.О., Борозенець В.В., Мазняков С.М., Пузік Н.Г. Лактозна непереносимість та їі зв'язок з показником походження серед населення Сходу України. Фактори експериментальної еволюиії організмів. 2019. № 24. C. 249-253.

7. Rasinperä H., Savilahti E., Enattah N.S., Kuokkanen M., Tötterman N., Lindahl H., Järvelä I., Kolho K.L. A genetic test which can be used to diagnose adult-type hypolactasia in children. Gut. 2004. Vol. 53 (11). P. 1571-1576. doi: 10.1136/gut.2004.040048.

8. Seppo L., Tuure T., Korpela R., Järvelä I., Rasinperä H., SahiT. Can primary hypolactasia manifest itself after the age of 20 years? A two-decade follow-up study. Scand J Gastroenterol. 2008. Vol. 43 (9). P. 1082-1087. doi: 10.1080/00365520802095485.

9. Bulhões A.C., Goldani H.A., Oliveira F.S., Matte U.S., Mazzuca R.B., Silveira T.R. Correlation between lactose absorption and the C/T-13910 and G/A-22018 mutations of the lactase-phlorizin hydrolase (LCT) gene in adult-type hypolactasia. Braz J Med Biol Res. 2007. Vol. 40 (11). P. 1441-1446. doi: 10.1590/s0100-879x2007001100004.

10. Fedota O.M., Lysenko N.G., Ruban S.Yu., Kolisnyk O.I., Goraychuk I.V. Effects of Allelic Polymorphisms in GH and GHR Geneson Production and Reproduction Parameters of Cattle (Bostaurus L., 1758) of the Aberdeen-Angus Breed Tsitologiyai Genetika. 2017. Vol. 5 (51). P. 38-49.

11. Fedota O., Roschenyuk L., Tyzhnenko T., Merenkova I.,Vorontsov V. Pharmacogenetic effects of methotrexate in Ukrainian patients depending on the mthfr genotypes (clinical cases). Georgian Medical News. 2018. Vol. 6 (279). P. 111-117.

12. Fedota O., Babalian V., Borozenets V., Mazniakov S., Lysenko N. Genetic aspects of lactase persistence in the Eastern Ukraine population. 7th Baltic Genetics Congress: abstracts, (Riga October 24-27, 2018). P. 202.

13. Coelho M., Luiselli D., Bertorelle G., Lopes A.I., Seixas S., Destro-Bisol G., Rocha J. Microsatellite variation and evolution of human lactase persistence. Hum. Genet. 2005. Vol. 117 (4). P. 329-339. doi: 10.1007/s00439-005-1322-z. 
БОРОЗЕНЕЦЬ В.В. ${ }^{1}$, БАБАЛЯН В.О. ${ }^{2}$, ФЕДОТА О.М. ${ }^{1}$

${ }^{1}$ Харківський наиіональний університет імені В.Н. Каразіна, Україна, 61058, м. Харків, майдан Свободи, 4, е-таil: amsfedota@gmail.com

${ }^{2}$ Харківська медична академія післядипломної освіти,

Україна, 61176, м. Харків, вул. Амосова, 58, е-mail: babalyanvladimir@gmail.com

\section{ГЕНЕТИЧНІ АСПЕКТИ ПЕРСИСТЕНЦІЇ ЛАКТАЗИ У ЛЮДЕЙ З РІЗНИХ ЕТНІЧНИХ ГРУП}

Mema. Оцінка генетичних аспектів лактозної толерантності (ЛТ) у людей з різних етнічних груп. Методи. У дослідженні зібрано та проаналізовано генеалогічну та медичну інформацію щодо українських, індійських, нігерійських, ізраїльських, єгипетських, палестинських, турецьких, йорданських студентів (n=361) та їх родичів першого ступеня споріднення $(\mathrm{n}=413)$. Статистичний аналіз проведено з використанням критерію нормальності Шапіро-Уілка, U критерію Манна-Уітні, $\chi^{2}$ та кореляційного аналізу за Спірменом. Результати. Фенотип ЛТ зустрічається у $69,9 \%$ українців, лактозної непереносимості - у 7,2\%. Найбільша частка осіб з ЛТ спостерігалася у вибірці нігерійців - 95,2 \%, найменша - у палестинців, 51,9\%. Частка батьків з ЛТ менша, ніж частка студентів $(\mathrm{r}=-0,529, \mathrm{p}<0,05)$. Показник ЛТ склав 72,7-95,2 \% для нігерійських, ізраїльських, єгипетських, турецьких, індійських студентів та 60-76,5\% для їх батьків. Фенотип ЛТ серед українських, палестинських йорданських студентів та їх батьків - 50-68, 8 \% та 53,9-70,9\%. Ймовірно, гіполактазія дорослого типу розвивається після 20 років і старше, що може свідчити про високий ступінь гетерозиготності. Серед студентів з Туреччини, Палестини, Сгипту виявлено найбільшу частку осіб з першої ступенем екзогамії батьків (82,6-85,5 \%), та найменший показник ЛТ $-51,9-72,3 \%,(\mathrm{r}=-0,786, \mathrm{p}<0,05)$. Встановлено позитивний зв'язок між ознаками гіполактазії та часткою осіб з першим ступенем екзогамії батьків $(\mathrm{r}=0,905, \mathrm{p}<0,05)$. Зміни метаболічного статусу з віком можуть бути передумовою розвитку мультифакторіальної патології. Висновки. Гіполактазія дорослого типу залежна від віку ознака. Встановлено зв'язки між показниками ЛТ та походженням.

Ключові слова: лактазна персистенція, лактозна непереносимість, екзогамія, генотипи. 